\title{
Identification of Character Values Developed in Early Childhood Education
}

\author{
Alwen Bentri \\ Educational Technology \\ Universitas Negeri Padang \\ Padang, Indonesia \\ alwenbentri@gmail.com
}

\author{
Abna Hidayati \\ Educational Technology \\ Universitas Negeri Padang \\ Padang, Indonesia \\ abnahidayati@gmail.com
}

\author{
Ulfia Rahmi \\ Educational Technology \\ Universitas Negeri Padang \\ Padang, Indonesia \\ ulfia@fip.unp.ac.id
}

\author{
Mutiara Felicita Amsal \\ Educational Technology \\ Universitas Negeri Padang \\ Padang, Indonesia \\ mutiaraamsal@gmail.com
}

\begin{abstract}
Character education in early childhood needs to be developed and identified so that the development of these values is appropriate to the early childhood development stage. This study aims to identify the character values that will be developed in early childhood education. The formulation of the problem in this research is what character values are developed in early childhood learning. The type of research is qualitative with data collection technique by observation and interview. Data were collected through teacher respondents on early childhood residing in Padang. The results showed that there are five different aspects of character developed in early childhood education that is, religious character, social character, personal value, caring character and environmental character.
\end{abstract}

Keywords-character values; religious; social; individual; personal; environment care, love the Fatherland.

\section{Introduction}

This study aims to identify the character values that should be developed in early childhood. Education is a way of developing the potential possessed by humans. Education becomes a medium for the glorification of human beings with the development of capabilities possessed by humans, the more reflected the human glory and the essence of humanity. Education is very important in the process of developing various potentials owned by humans. [1]

Character education is the real education through the understanding of concepts, applications and reflections and the regulation of the nature of self as intelligent and autonomous human capable of doing the best for themselves [2]. Character education is an important aspect that should be developed in the pattern of early childhood education. Early childhood education at the age of 4 to 6 years is a golden period so it should be the attention of all parties to develop the values of these characters. To optimize the values of characters developed it is necessary to identify the values of positive characters in accordance with the stages of development in early childhood education. The identification of these character values is obtained through observation and interviews conducted on a number of early childhood education teachers and early childhood education experts who find an indicator of ownership of character values in early childhood education.
Early children have different characteristics than adults, because early childhood grows and develops in many different ways. Kartini (1990: 109) explains that early childhood has characteristics 1) is naive egocentric, 2) has social relations with objects and humans are simple and primitive, 3 ) there is a physical and spiritual unity that is almost inseparable as one totality, 4) the physiognomic attitude of life, that is, the child directly gives the attributes / outer nature or material to each of his / her life. [3]

Other opinions about the characteristics of early childhood are presented by Hartati (2005: 8-9) as follows: 1) have great curiosity, 2) is unique, 3) likes to fantasize and imagine, 4) potential time to learn, 5 ) have egocentric attitudes, 6) have a short concentration of vulnerable, 7) are part of a social being. Based on the characteristics that have been submitted it can be seen that children aged 5-6 years (group B), they can perform coordinated movements, language development is good and able to interact socially. This age is also a sensitive time for children to learn the language. With good movement coordination the child is able to move the hands to realize his imagination into the form of drawing, so the use of children's drawings can help improve children's speech. [4] [5]

In the context of early childhood learning that has been done in a number of schools rarely use video as one of the tools in implementing learning.

\section{METHOD}

The research method is qualitative descriptive. Data collected through observation and interviews conducted on the respondents namely teachers of early childhood education in the city of Padang. Respondents were taken by purposive sampling is some Early Childhood Education institutions located in North Padang Sub district which is UNP assisted institution. Data were analyzed using Miles and Huberman analysis technique

\section{RESULT AND DISCUSSION}

Education is one effective way in shaping the character of learners, and then it is natural implementation of our education in school in particular, has the essence of value education related to the education of the characters of students. Kemendiknas argued that the implementation of character education is done through three stages, namely knowledge 
(knowing), implementation (acting), and habits (habit). [6][7][8].

Based on interviews conducted with a number of teachers can be identified aspects of character values developed divided into five categories namely

1. Religious Character

The value of the religious character is the character associated with love and piety to God Almighty. The indicators of religious character values are:

\begin{tabular}{|c|c|}
\hline Character & Indicator \\
\hline $\begin{array}{ll}\text { Love } & \text { To } \\
\text { God } & \\
\text { Almighty } & \end{array}$ & $\begin{array}{l}\text { a. Students greet his teacher before going } \\
\text { to class } \\
\text { b. Students praying before and after doing } \\
\text { activity } \\
\text { c. students praying in congregation } \\
\text { d. Students read Holy Qur'an or Iqra } \\
\text { e. Glad to listen and retell the story } \\
\text { f. Nuanced imtag } \\
\text { g. Students pray before and after starting } \\
\text { other activities. }\end{array}$ \\
\hline Honesty & $\begin{array}{l}\text { a. The students reports to the teacher that } \\
\text { an object was found not belonging to } \\
\text { him. } \\
\text { b. Students used to retum objects that are } \\
\text { not hers }\end{array}$ \\
\hline
\end{tabular}

\section{Individual Personal Character}

Individual or personal characters are the character values associated with the individual or personal development of the student in order to become a formidable individual.

\begin{tabular}{|l|ll|}
\hline Character & Indicator \\
\hline Confidence & a. & Students work with friends. \\
& b. & Students want to share food or toys with friends. \\
& c. & Students do not like to make noise or disturb friends \\
& d. & Nice to be friends with anyone \\
e. & Always greeted when met \\
\hline Independent & a. & Students put down his bag and take care of his own \\
& b. & luggage. \\
& c. & Students can choose their own toys \\
& d. & Students picks up his own toys \\
& e. & Students cleans up his own room \\
\hline Creative & a. & Students love to make something from the material \\
& & around it \\
& b. & Have different ways of utilizing tools and play \\
& c. & materials \\
& d. & Students trying new game \\
& e. & Students is working on something new \\
& a. & Tidied equipment / toys that have been used \\
& b. & Keep his own belongings \\
& c. & Also take care of school toys \\
& d. & Glad to run the task given by parents or teachers \\
& e. & Maintain the property of others and the public \\
\hline Responsibility & a. & Students focus on the game they face \\
& b. & Students trying to overcome the difficulties he faces \\
& & without or with little help \\
& c. & Students love to successfully complete the task well \\
& d. & Students trying to complete the task until completed \\
\hline Humble & a. & Happy to be friends with everyone \\
& b. & Students speak politely \\
& c. & Students share toys with friends \\
& d. & Students will listen to the teacher's instructions. \\
& e. & Students does not make fun of his friend \\
\hline Work hard & a. & Able to lead peers \\
& b. & Students becomes a prayer imam \\
& c. & Students becomes group leader \\
d. & Students helps his friend \\
\hline & & \\
& &
\end{tabular}

\section{Social Character}

The social character is the character associated with the ownership of social values for learners.

\begin{tabular}{|l|ll|}
\hline Character & Indicator \\
\hline Tolerance & a. & Students work with friends. \\
& b. & Students want to share food or toys with \\
& friends. \\
& c. & Students do not like to make noise or disturb \\
& friends \\
& d. & Nice to be friends with anyone \\
e. & Always greeted when met \\
\hline Politeness & a. & Students listen to others talk \\
& b. & Students do not mock others \\
& c. & Students can do good habits \\
& d. & Can be patient waiting to talk \\
& e. & Can do the habit of saying hello when \\
& & meeting or separating \\
\hline Cooperation & a. & Students love working with friends \\
& b. & Students love helping, and helping friends \\
& c. & Glad to give support to friends who working \\
& d. & Can show empathy to others \\
& e. & Like to calm a friend who feels sad or scared \\
\hline
\end{tabular}

4. Character Caring for the Environment

Character of environmental care is character related to child concern to environment which is realized with activity which keep and keep environment to remain beautiful and not damage it.

\begin{tabular}{|c|c|}
\hline Character & Indicator \\
\hline $\begin{array}{l}\text { Environmental } \\
\text { Care }\end{array}$ & $\begin{array}{l}\text { a. Students throw garbage into trash } \\
\text { b. Students watering the plants } \\
\text { c. Students help plant crops and care for } \\
\text { them } \\
\text { d. Keep the learning environment from dirt }\end{array}$ \\
\hline
\end{tabular}

\section{Character of Love Country}

Character of love of the homeland is the embodiment of the character values that indicate the love of the students to the homeland and nation. The indicators are as follows:

\begin{tabular}{|c|c|}
\hline Character & Indicator \\
\hline $\begin{array}{l}\text { Love of } \\
\text { Motherland }\end{array}$ & $\begin{array}{l}\text { a. Sing the mandatory national anthem } \\
\text { b. Know and understand the symbol of the } \\
\text { country (garuda, flag, president, etc.) } \\
\text { c. Students follows the flag ceremony } \\
\text { d. Students make friends with all their } \\
\text { friends by not distinguish between tribe } \\
\text { and religion }\end{array}$ \\
\hline
\end{tabular}

Efforts to realize the nation's civilization through character education of the nation is never separated from the educational environment both within the family, school and community. Teachers have a great responsibility in generating a characteristic, cultured and moral generation [9].

Many factors can influence the formation of the character of the learners, including (1) instinct factor, (2) custom factor, (3) heredity, (4) environmental factor. [10][6].

\section{CONCLUSION}

Based on description it can be concluded that the indicators of characters values developed are divided into five main characters that is divine or religious character, personal or individual character, social character, environmental caring character and the character of love motherland. 


\section{References}

[1] D. Suryana, "Pendidikan Anak Usia Dini: Teori dan Praktek Pembelajaran." Padang: UNP Press, 2013.

[2] A. Olim, "Mencari metode pendidikan karakter untuk PAUD: Belajar berbasis layanan (service learning)," in Proceedings of The 4th International Conference on Teacher Education, 2010, pp. 146-161.

[3] Ka. KArtini, Psikologi Anak. Bandung: CV. Mandar.

[4] S. Hartati, "Perkembangan Belajar Pada AUD.” Jakarta: Depdiknas, Direktorat Jendral Pendidikan Tinggi, Direktorat Pembinaan Pendidikan Tenaga Kependidikan dan Ketenagaan Perguruan Tinggi, 2005.

[5] N. MAHYUDDIN, Y. SYUKUR, and A. HIDAYATI, "EFEKTIVITAS PENGGUNAAN VIDEO CAMERA DALAM PEMBELAJARAN DAN IMPLIKASINYA TERHADAP PELAYANAN ANAK USIA DINI (USIA 4-6 TAHUN) DI KOTA PADANGNENNY MAHYUDDIN," JPUD-Jurnal Pendidik. Usia
Dini, vol. 10, no. 1, pp. 45-60, 2016.

[6] M. Yunus, "UPAYA GURU MEMBENTUK KARAKTER BANGSA PADA ANAK USIA DINI MELALUI PROSES PEMBELAJARAN DI YAYASAN RAUDATUL ATHFAL (RA) FATHUN QARIB," Serambi Akad., vol. 3, no. 2, 2016.

[7] Kemendiknas, Panduan Pelaksanaan Pendidikan Karakter. Jakarta: Badan Penelitian dan Pengembangan. Pusat Kurikulum dan Pembukuan, 2011.

[8] H. Cahyono, "PENDIDIKAN KARAKTER: STRATEGI PENDIDIKAN NILAI DALAM MEMBENTUK KARAKTER RELIGIUS," Ri'ayah J. Sos. dan Keagamaan, vol. 1, no. 2, pp. 230$240,2016$.

[9] K. Wardani, "Peran Guru Dalam Pendidikan Karakter Menurut Konsep Pendidikan Ki Hadjar Dewantara," in Proceeding of The 4th International Conference on Teacher Education; Join Conference UPI \&UPSI, 2010, pp. 8-10.

[10] D. M. A. Zubaedi and M. Pd, "Desain Pendidikan Karakter," Jakarta: Kencana, 2011. 